\title{
CU(II)-GLYPHOSATE SYSTEM: A STUDY BY ANODIC STRIPPING VOLTAMMETRY AND THE INFLUENCE ON CU ADSORPTION BY MONTMORILLONITE
}

\author{
MORILLO, E.; MAQUEDA, C.; BEJARANO, M.; MADRID, L. AND \\ UNDABEYTIA, T.
}

Instituto de Recursos Naturales y Agrobiologia. CSIC. Apdo. 1052. 41080 Sevilia (Spain).

(Received in Germany 14 February 1994; accepted 12 April 1994)

\section{ABSTRACT}

The influence of the pesticide glyphosate (GPS) on the adsorption of Cu (II) on montmorillonite has been examined. The complexation of CU(II) with GPS was studied using anodic stripping voltammetry in differential pulse mode (DPASV). It has been concluded that the complexes present a labile behaviour and GPS shows a low but noticeable degree of heterogeneity, probably due to complexation of Cu bv more than one GPS species. CU(II) adsorption on montmorillonite is drastically decreased in the presence of GPS, due to several reasons: decrease in tree $\mathrm{Cu}$ concentration due to formation of Cu-GPS complexes; surface loading of GPS on montmorillonite, obstructing interlamellar $\mathrm{Cu}^{2+}$ adsorption and competitive effect between protons and $\mathrm{Cu}^{2+}$ for interlamellar positions. 


\section{INTRODUCTION}

Clay minerals and organic matter play important roles in controlling the mobility of heavy metals in soils and sediments, and the chemical forms of these metals are also important in determining whether or not they can be biologically available. Consequently, metal/organic matter/mineral interactions are of wide ranging importance in environmental studies (Varadachar et al., 1991). In additiori to soil organic matter, other organic compounds used in agricultural practices (fertilizers, pesticides) or present in wastes added to soils as manure can also decrease or enhance the mobility of heavy metals in soils or sediments (Bejarano and Madrid, 1992). However, little attention has so far been given to the phenomena involved in the joint reaction of metals and pesticides with soils or clay minerals, although some investigations have recently been carried out using montmorillonite as adsorbent (Morillo and Maqueda, 1992; Undabeytia et al., 1994).

The herbicide glyphosate (GPS) is a very interesting compound to be studied in relation to its behaviour with soil components when heavy metals are present. This pesticide is extensively used in agriculture, but it shows only low herbicidal activity when applied to the soil. This is a consequence of two factors: the moderate adsorption of this herbicide by the soils constituents, and its low intrinsic toxicity due to its rapid degradation by microorganisms to non-phytotoxic products. In relation to GPS adsorption by clays, it is known that the exchangeable cations of the clay mineral influence its adsorption capacitv (Sprankle et al., 1975b; Shoval and Yariv, 1979; McConnell and Hossner, 1985; Glass, 1987), since this pesticide coordinates strongly to metal ions, particularly to transition metal ions (Glass, 1984; Subramanian and Hoggard, 1988; McBride, 1991). The effect of chelation of metals may have some significance in the soil environment, through the frequently higher solubility of the complexes formed, affecting their distribution in soils and sediments.

The objectives of this paper comprise two parts: 1 . To study the complexation of Cu(II) with GPS using anodic stripping voltammetry in differential pulse mode (DPASV), to estimate the average stability of the complexes and the degree of heterogeneity of the ligand in this system. 2. To investigate the influence of GPS on the adsorption of $\mathrm{Cu}($ II) by the clay mineral montmorillonite.

\section{MATERIALS AND METHODS}

The clay mineral used was a standard montmorillonite from Arizona (designed SAZ-1) (Van Olphen and Fripiat, 1979), supplied by the Clay Mineral Society (Source Clay Minerals Repository). Its cation exchange capacity (CEC) is $120 \mathrm{meq} / 100 \mathrm{~g}$ ( $80 \%$ in Ca form), and it was used as received.

The pesticide glyphosate ( $\mathrm{N}$-[phosphonomethyl] glycine), was used. This pesticide is a nonselective, non-residual herbicide, with solubility in water of $12 \mathrm{~g} \mathrm{~L}^{-1}$ at $25^{\circ} \mathrm{C}$. Glyphosate has a zwitterion structure depending on the $\mathrm{pH}$, the proposed dissociation diagram and protonation $\mathrm{pK}\left(a \mathrm{t} 25^{\circ} \mathrm{C}\right.$ ) being given in scheme 1. (Motekaitis and Martell, 1985). Starting with totally deprotonated GPS $\left(\mathrm{G}^{3}\right.$ ) the 
successive protonation sites are the amino nitrogen, the phosphonate oxygen, and finally the carboxylate oxygen atom.

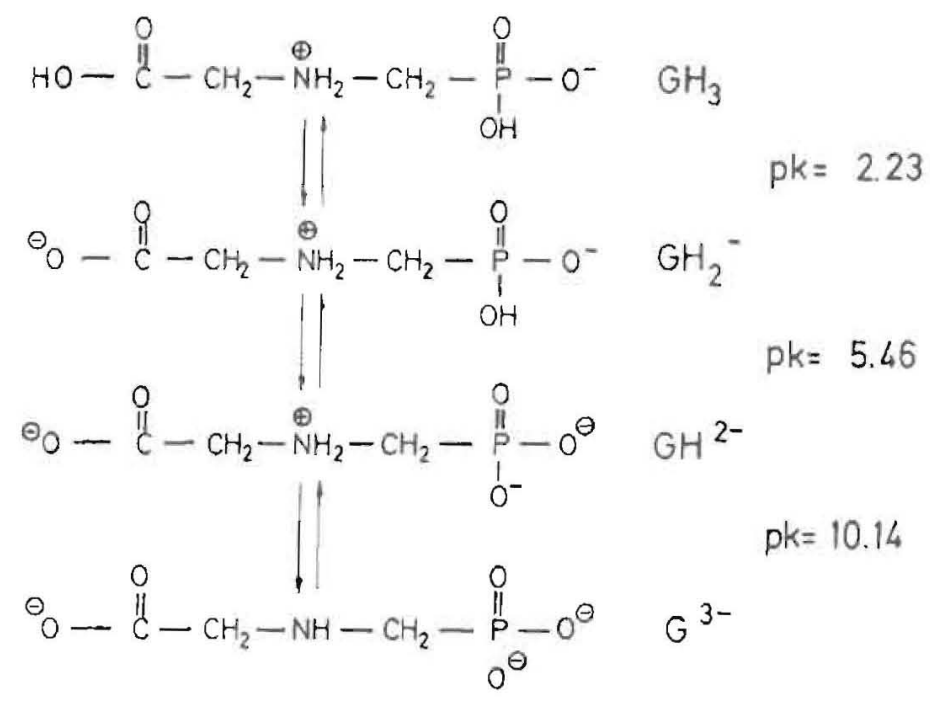

Scheme 1. Species of GPS depending on the $\mathrm{pH}$ and protonation constants (from Motekaitis and Martell, 1985).

Duplicate adsorption experiments were done by mixing $0.1 \mathrm{~g}$ of clay mineral with $0.01 \mathrm{M} \mathrm{NaCl}$ solutions containing various concentrations of glyphosate $(0.2,0.5,1.0,2.0 \mathrm{mM})$ and/or $\mathrm{Cu}(5,10,20$, $30 \mathrm{ppm}$ ) in $50 \mathrm{ml}$ polypropylene centrifuge tubes. The samples were shaken for $24 \mathrm{~h}$ at $20 \pm 1^{\circ} \mathrm{C}$. $\mathrm{Cu}$ adsorbed was calculated from the differences between its concentrations before and after equilibrium using atomic absorption spectrometry (AAS) (Perkin-Elmer 703 spectrometer was used), with nitrous oxide-acetylene flame. This was used instead of air-acetylene flame, since with the latter, measured Cu concentrations in the presence of GPS were always lower than the real values, as a consequence of formation of Cu-GPS complexes, which need a more energetic flame to destroy them. The inorganic cations (principally $\mathrm{Ca}^{2+}$ and $\mathrm{Mg}^{2+}$ ) released during adsorption experiments were also determined by AAS (in air-acetylene flame). Cu adsorption isotherms were obtained by plotting the amount of $\mathrm{Cu}$ adsorbed, $\mathrm{C}_{\mathrm{s}}\left(\mu \mathrm{mo} \mathrm{g}^{-1}\right)$, versus the equilibrium concentration, $\mathrm{C}_{\mathrm{a}}\left(\mu \mathrm{mol} \mathrm{L}^{-1}\right)$.

Anodic stripping voltammetry in differential pulse mode (DPASV) was carried out in $0.01 \mathrm{M} \mathrm{KNO}$, solutions. Glyphosate was titrated at $\mathrm{pH}=3$ with $\mathrm{Cu}\left(\mathrm{NO}_{3}\right)_{2}$ solutions at $20^{\circ} \mathrm{C}$. A Metrohm $646 \mathrm{VA}$ polarographer was used. Hanging mercury drop electrode (HMDE), $\mathrm{Ag} / \mathrm{AgCl}$ electrode and platinum counter electrode were used as working, reference and auxiliary electrodes, respectively.

The deposition time was $100 \mathrm{~s}$ followed by $30 \mathrm{~s}$ without stirring before the potential scan. The initial potential applied was $-0.9 \mathrm{~V}$ and the scan rate was $6 \mathrm{mV} \mathrm{s}^{-1}$.

The $\mathrm{pH}$ was checked during the titration with a $9103 \mathrm{SC}$ semimicro Orion combination electrode and adjusted to the chosen value by adding small volumes of $0.1 \mathrm{M} \mathrm{HNO}_{3}$ or $\mathrm{KOH}$.

The dissolved oxygen was removed from solutions in the polarographic cell by bubbling $99.9995 \%$ purity nitrogen. 


\section{Study by DPASV of the complexation of GPS with Cu(II).}

The formation process of GPS-Cu(II) complex can be schematically represented as:

$$
M+I=M L
$$

where $L$ stands for each complexing site of the GPS molecule, $M$ the free metal (in this case Cu) and ML each 1:1 complex (Pinheiro et al., 1994). This simplified model implies that if two or more groups are bound to a metal ion, all these groups are taken as one coordination site, thus only complexes of 1:1 type are considered.

Considering the pK values of GPS (scheme 1), it can be calculated that more than $95 \%$ of the herbicide present, under the conditions used in DPASV experiments is in either of the following forms (Motekaitis and Martell, 1985):

$$
\mathrm{GH}_{3}=\mathrm{GH}_{2}^{-}+\mathrm{H}^{+}
$$

and other ionization equilibria can be considered negligible at this $\mathrm{pH}$ value. The ratio $\mathrm{GH}_{2} / \mathrm{GH}_{3}$ can be calculated to be 5.9 .

The average stability parameter of the metal complex (Buffle, 1988) can be expressed:

$$
K=\frac{[M L]}{[M][L]}
$$

where [L] represents the concentration of ligand not bound to the metal $M,[M]$ the tree metal concentration and $[\mathrm{ML}]$ the complex concentration.

The total concentration of glyphosate, $C_{L}$, was constant and in excess during the titration $\left(3.8 \times 10^{-4} \mathrm{M}\right)$, and the metal concentration was in the range 0.11-3.9 $\mu \mathrm{M}$.

Figure 1 shows the variation of the peak current versus the total metal concentration added $\mathrm{C}_{M}$, in the absence $\left(i_{p}{ }^{M}\right)$ and presence $\left(i_{p}{ }^{M-L}\right)$ of ligand.

From the voltammograms (not shown) similar values can be observed for the peak widths $W$., $(52 \mathrm{mV})$ of $M$ and $M+L_{i}$ on the other hand, Figure 1 shows that there is the same relationship between $C_{M}$ and $i_{p}$ in the presence and absence of ligand, so it can be concluded (Bejarano et al, 1994) that:

a) The complex presents a labile behaviour in DPASV measurements in the concentration range studied.

b) $D_{M L}=D_{M}=D_{C u}=7.1 \times 10^{-6} \mathrm{~cm}^{2} \mathrm{~s}^{-1}$ (Simoes Gonçaives, 1990) where $D_{M}$ and $D_{M L}$ are respectively the diffusion coefficients of the copper ion and the complex formed. 
Figure 1

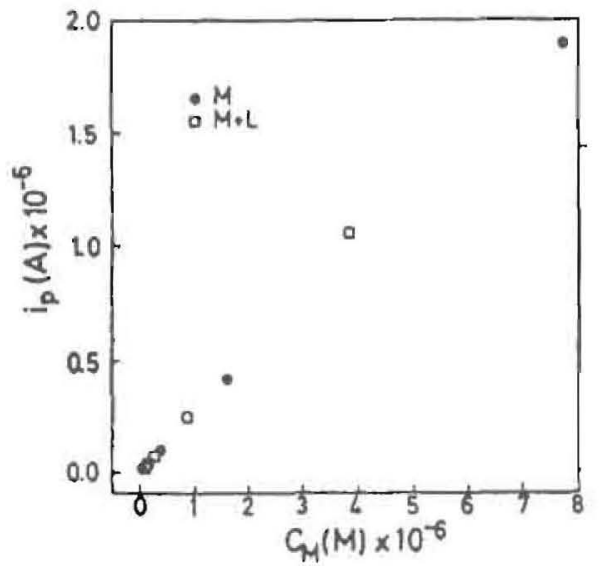

Figure 2

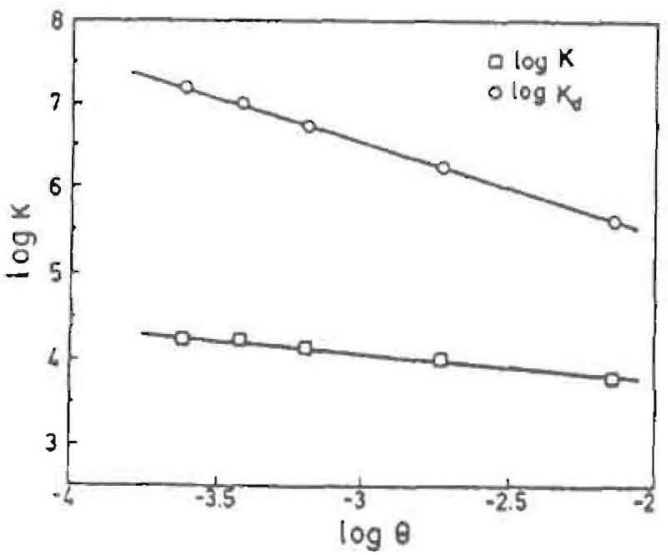

Figure 1. Peak current $i_{p}$ versus total Cu concentration in the presence of glyphosate $(M+L)$ and in its absence $(\mathbf{M})$.

Figure 2. Average stability parameter $K$ and differential equilibrium function $K_{f}$ for glyphosate-Cu complex versus the degree of occupation of sites $\theta,(\log / \mathrm{log})$.

The voltammograms can also show that the peak potential in the presence of GPS, $E_{\rho}^{M+L}$, is always lower than in the absence of ligand, $E_{p}{ }^{M}$. Provided that $i_{p}{ }^{M}-i_{\rho}{ }^{M+L}$, it can be shown (Bejarano et al., 1994) that the fact that $E_{p}{ }^{M+L}<E_{p}{ }^{M}$ implies a fast process of formation of the complex.

Table 1.- Determination of the conditional stability constant $(K)$ Irom $E_{p}$ experimental values.

\begin{tabular}{|c|c|c|}
\hline$C_{M}(M)$ & $\Delta E_{p}(\mathrm{mV})\left(^{\circ}\right)$ & $\log \mathrm{K}\left(\mathrm{mol}^{-1} \mathrm{~L}\right)$ \\
\hline $1.1 \times 10^{-7}$ & -26 & 4.2 \\
$1.7 \times 10^{-7}$ & -26 & 4.2 \\
$2.9 \times 10^{-7}$ & -24 & 4.1 \\
$8.8 \times 10^{-7}$ & -21 & 4.0 \\
$3.9 \times 10^{-6}$ & -16 & 3.8 \\
\hline
\end{tabular}

(") $\Delta E_{p}=E_{p}{ }^{M} \cdot E_{p}{ }^{M+L}{ }^{-}$Shith of the peak potential in the presence of ligand compared to the value In its absence.

The conditional stability constant of the complex GPS-Cu(II), K (Table I), can be obtained from the Deford-Hume expression for labile complexes and $D_{M L}=D_{M}$, in the presence of an excess of ligand, so 
that the ligand not bound at the electrode surface can be considered the same as the total concentration, $C_{L}:$

$$
E_{p}=E_{p}^{M}-E_{p}^{M+L}=\frac{R T}{n F} \ln \left(1+K C_{L}\right)
$$

The average value found was $\log K=4.1 \pm 0.2$, quite similar to that found by Glass (1984) $(4.27 \pm 0.07)$ at $\mathrm{pH}=5$. At this $\mathrm{pH}$ the predominant equilibrium of GPS is:

$$
\mathrm{GH}_{2}^{-}=\mathrm{GH}^{2-}+\mathrm{H}^{+}
$$

and it can be calculated that the ratio $\mathrm{GH}_{2}{ }^{2} / \mathrm{GH}^{2-}$ is about 3.24. Therefore, the same ligand is likely to be involved at both $\mathrm{pH}$ values, in agreement with the closeness of both results for logk.

Table 1 shows that the parameter $\mathrm{K}$ calculated from equation (2) is not exactly constant. There is a slight decrease as $\mathrm{C}_{M}$ increases, i. e, the degree of occupation of sites. This means that glyphosate does not behave as a simple ligand, and it can be attributed to the existence of two different complexing groups $\left(\mathrm{COOH}\right.$ and $\left.\mathrm{PO}(\mathrm{OH})_{2}\right)$, causing some degree of heterogeneity of the ligand.

The heterogeneity of the organic ligand can be interpreted by using the differential equilibrium function, $K_{d}$. In fact $K_{d}$ is more specific for a range of sites than $K$ (Gamble et al., 1980; Buffle, 1984).

If the ligand concentration is maintained constant along the titration with the metal ion, $\mathrm{K}_{\mathrm{d}}$ is given by equation (3) (Buffle, 1984; Buffle et al., 1990):

$$
K_{d}=-\frac{\alpha^{2}}{C_{M}}\left[\frac{1}{1+(\alpha-1) \frac{d \ln C_{M}}{d \ln \alpha}}\right]
$$

where $\alpha=C_{\mathcal{M}} /[M]$. According to Filella et al., (1990), metal complexation by many natural, heterogeneous complexants can be represented by a Freundlich-type equation. Since the value of $K_{d}$ is mainly controlled by the complexing sites corresponding to half saturation $(\theta=0.5)$, the following form of Freundlich equation can be deduced (Buffie et al., 1990):

$$
\log \theta=\Gamma \log K_{o d}-\Gamma \log K_{d}
$$

where $K_{\infty}$ is the value of $K_{d}$ for $\theta=1$ and $\Gamma$ is the heterogeneity parameter (equal to 1 for a simple ligand, decreasing as heterogeneity increases). The values of $\log K_{d}$ and $\log K$ versus $\log \theta$ are presented in Figure 2. It can be seen that $K_{d}$ is much higher than $K$, mainly for low $\theta$ values, because in this range the metal is complexed by the strongest sites. Moreover, $K_{d}$ has a more marked dependence upon $\theta$, as expected from its differential nature.

The value obtained for $\Gamma$ from the slope of $\log K_{d}$ versus $\log \theta$ was 0.93 , indicating a low but noticeable degree of heterogeneity. 


\section{Adsorption of Cu on montmorillonite in the presence of GPS.}

Before studying the reaction, it is useful to know the characteristics of the GPS-CU(II) solutions used. Taking into account the protonation oK values of GPS (scheme 1) and those of GPS-Cu complexes, it has been possible to calculate the distribution of metal ion and metal chelate species in each solution before equilibration with montmorillonite. The metal-chelate species which have been considered to form in significant proportion under our conditions are 1:1 chelate CuG and CuHG complexes ( $G$ being the ligand glyphosate, with log metal-chelate stability constants of 11.93 and 15.85 , respectively). Under the conditions of this study the formation of the metal hydroxide or $\mathrm{CuCl}^{+}$is negligible. As shown by Motekaitis and Martell (1985), most of metal ions also form 2:1 ligand:metal complexes when GPS concentration is more than twice that of the metal, but formation of such a $2: 1$ complex in our system is not likely because its formation takes place at $\mathrm{pH}>7$, higher than the maximum $\mathrm{pH}$ in this study (4.96) (Table 2).

Table 2.- $\mathrm{pHS}$ of GPS + Cu solutions before $\left(\mathrm{pH}_{1}\right)$ and after $\left(\mathrm{pH}_{2}\right)$ equilibrating with montmorillonite

\begin{tabular}{|c|c|c|c|c|c|c|c|c|}
\hline $\begin{array}{c}\text { Cu concentration } \\
\text { (ppm) }\end{array}$ & \multicolumn{7}{|c|}{$\begin{array}{c}\text { GPS concentration } \\
\text { (mM) }\end{array}$} \\
\hline & \multicolumn{2}{|c|}{0.2} & \multicolumn{2}{c|}{0.5} & \multicolumn{2}{c|}{1.0} & \multicolumn{2}{c|}{2.0} \\
\cline { 2 - 9 } & $\mathrm{pH}_{1}$ & $\mathrm{pH}_{2}$ & $\mathrm{pH}_{1}$ & $\mathrm{pH}_{2}$ & $\mathrm{pH}_{1}$ & $\mathrm{pH}_{2}$ & $\mathrm{pH}_{1}$ & $\mathrm{pH}_{2}$ \\
\hline & & & & & & & & \\
5 & 3.90 & 4.96 & 3.26 & 4.49 & 3.03 & 3.80 & 2.81 & 3.14 \\
10 & 3.54 & 4.69 & 3.20 & 4.19 & 3.01 & 3.66 & 2.80 & 3.13 \\
20 & 3.35 & 4.47 & 3.17 & 3.93 & 2.99 & 3.58 & 2.78 & 3.12 \\
30 & 3.30 & 4.55 & 3.15 & 3.80 & 2.97 & 3.51 & 2.76 & 3.07 \\
\hline
\end{tabular}

Figure 3 shows that, in general, the proportion of CuG species in the initial solutions (before montmorillonite equilibration) is low in relation to that of $\mathrm{Cu}$ and CUHG. For low concentrations of GPS, free $\mathrm{Cu}$ predominates over CUHG species, but the amount of CuHG increases for increasing concentrations of GPS, and becomes higher than free $\mathrm{Cu}$ for 1.0 and $2.0 \mathrm{mM}$ GPS concentrations. Although in our study there are many cases with an excess of GPS compared to Cu total concentration (up to a ratio GPS/Cu=25), not all the Cu present in solution is in complexed forms, and a significant proportion is in the $\mathrm{Cu}^{2+}$ form. 


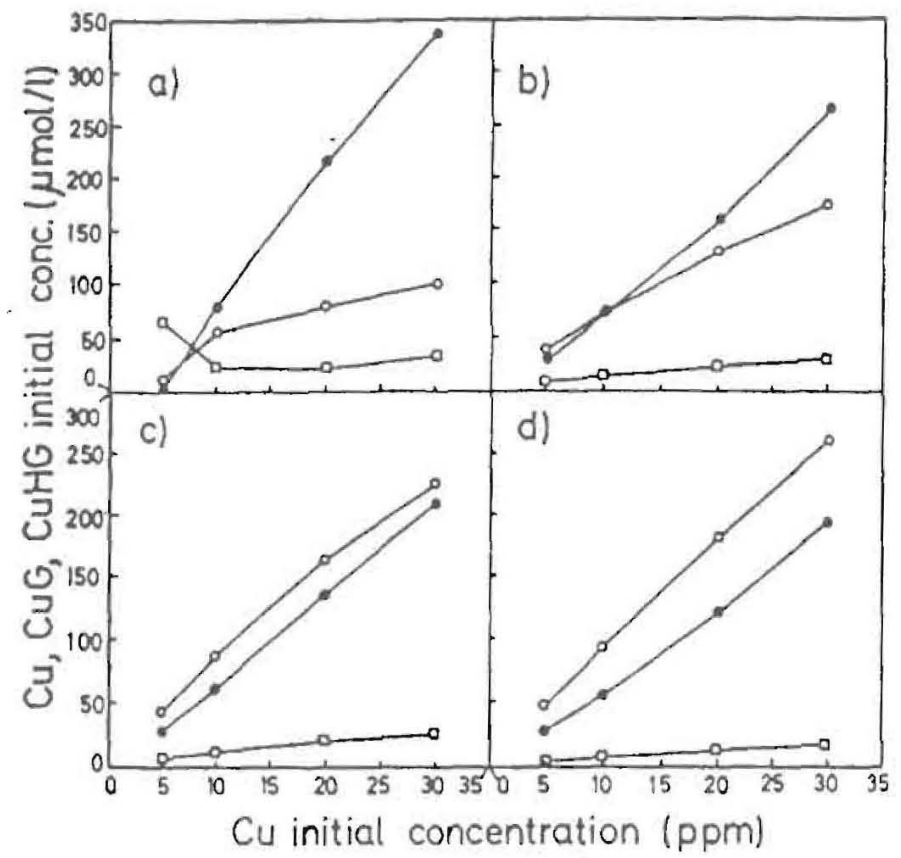

Figure 3. Distribution curves of free $\mathrm{Cu}(\bullet), \mathrm{CuHG}(\mathrm{O})$ and $\mathrm{CuG}$ (a) species lor GPS concentration 0.2 (a), 0.5 (b), 1.0 (c) and 2.0 (d) $\mathrm{mM}$, versus initial Cu concentration.

Figure 4 shows the adsorption isotherms of $\mathrm{Cu}$ on montmorillonite for GPS concentrations $0,0.2$, $0.5,1.0$ and $2.0 \mathrm{mM}$, It can be observed that the adsorption of $\mathrm{Cu}$ is strongly decreased in the presence of the herbicide. The data of all curves conformed to the Freundlich equation ( $\mathrm{Cs}=\mathrm{kC}^{1 / n}$ ) over the range of concentrations used. Freundlich $k$ value (expressed in $\mu \mathrm{mol} \mathrm{g}^{-1}$ ) for adsorption of $\mathrm{Cu}$ from GPS-free solutions is 12.95, and $<0.86$ for adsorption of $\mathrm{Cu}$ in the presence of GPS.

The decrease in $\mathrm{Cu}$ adsorption when GPS is present can be an effect of a decrease in free $\mathrm{Cu}$ concentration due to the formation of CU-GPS complexes. However, $\mathrm{pH}$ values corresponding to each point of the adsorption curves (Figure 4) decrease as GPS concentration increases (Table 2), which can also cause a decrease in adsorption.

Another point which should be clarified concerns the possible adsorption of CU-GPS complexes on the clay mineral. This adsorption is not possible in the interlamellar space (Sprankle et al., 1975a; Hance, 1976; Shoval and Yariv, 1979). These authors suggested that GPS is bound to the soil constituents through the phosphonic acid radical by a mechanism similar to that of inorganic phosphate which occurs on edge positions of clay minerals. Organic matter, amorphous alumina, and ferric oxides are also suitable substrates for GPS adsorption. 


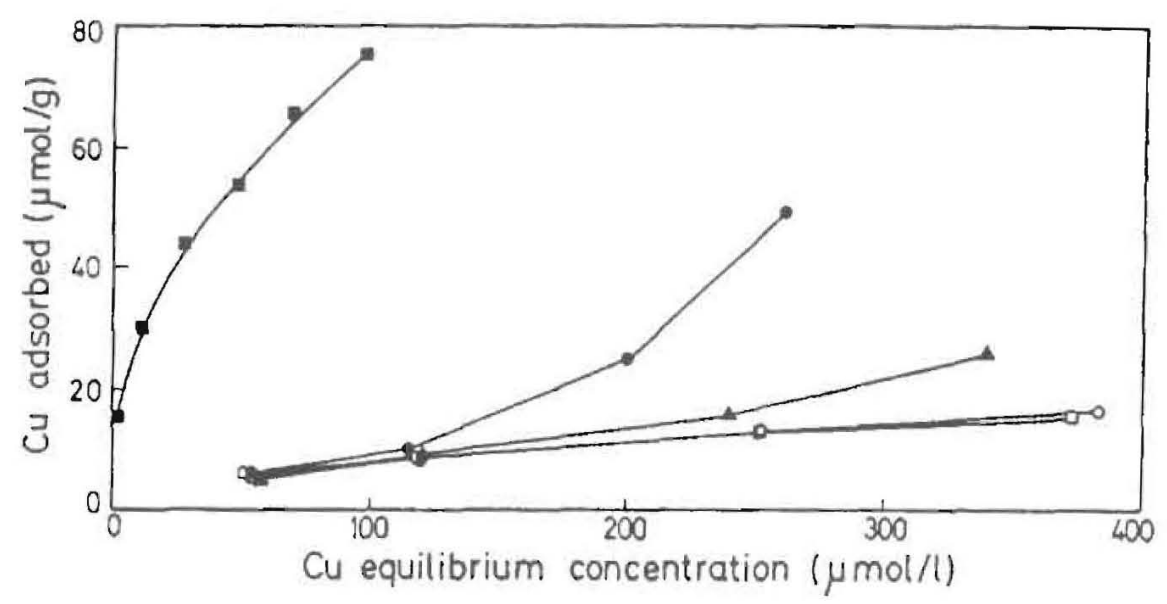

Figure 4. Adsorption isotherms of Cu on montmorillonite for various GPS concentrations: $0(\mathbf{D}), 0.2(\boldsymbol{O}), 0.5(\mathbf{\Delta}), 1.0(\square)$, $2.0(0) \mathrm{mM}$.

According to Shoval and Yariv (1979) adsorption of GPS on interlamellar space of montmorillonite from aqueous solutions occurs only in the presence of excess of soluble $\mathrm{Al}(\mathrm{III})$ and $\mathrm{Fe}$ (III) ions, forming a coordination compound with the polyvalent cation. Therefore, adsorption of GPS, or even CU-GPS complexes, on edges of the clay crystals may obstruct the access of $\mathrm{Cu}^{2+}$ ions to the interlayer positions. McConnell and Hossner (1985) found that the maximum adsorption of GPS on montmorillonite, under

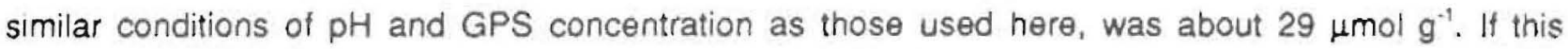
adsorption can be attributed only to edge positions, this value is high enough as to suggest that the obstruction for the access of $\mathrm{Cu}^{2 *}$ to interlayer positions can be significant.

Some effects on the concavity of the curves in Figure 4 can be observed as GPS concentration increases. The negative concavity of the GPS-free curve is sharply changed to positive for low GPS concentrations $(0.2$ and $0.5 \mathrm{mM})$, which could be caused by complexation of part of the metal present by GPS, causing the measured Cu concentration to be higher than the actual free $\mathrm{Cu}^{2 *}$ concentration controlling the reaction. This effect should be noticeable especially for lower Cu concentrations. When higher GPS concentrations are present, this effect would also be noticeable for higher Cu levels. Therefore the isotherms for higher GPS concentrations would tend to lose the positive concavity, as observed in Figure 4 for 1 and 2 mM GPS. 


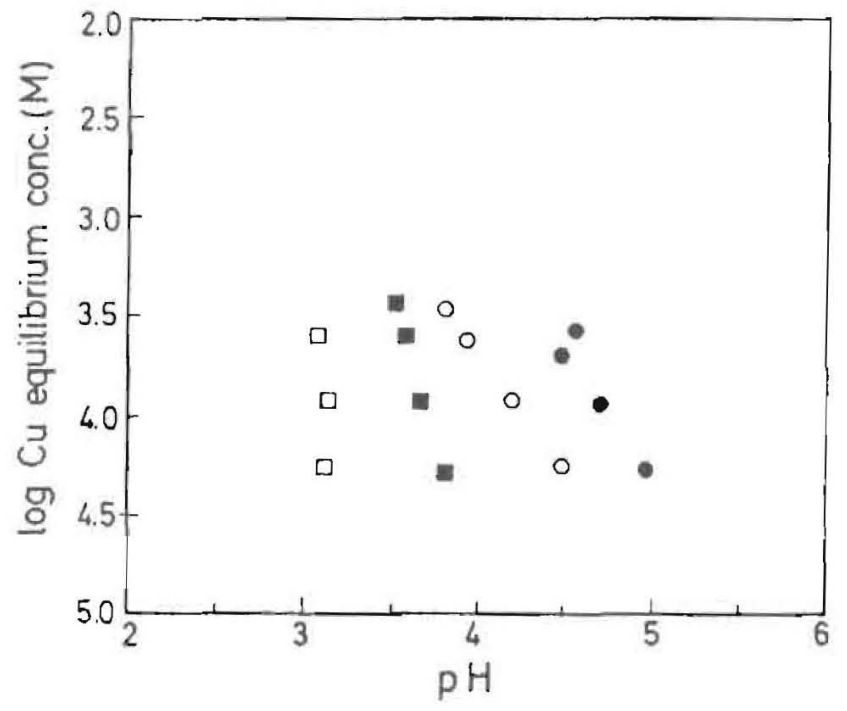

Figure 5. Relationship between equilibrium $\mathrm{Cu}$ concentration and pH for GPS concentrations $0.2(\bullet), 0.5(0), 1.0(\mathbf{\square})$ and 2.0 (口) $\mathrm{mM}$.

Adsorption of GPS on external surfaces of montmorillonite can be the explanation of Figure 5 , in which the relationship between equilibrium $\mathrm{Cu}$ concentration and $\mathrm{pH}$ is shown for the various GPS concentrations. Separate relationships are found between these two variables for each GPS concentration, instead of a single line as would be expected if $\mathrm{pH}$ were the master variable determining $\mathrm{Cu}$ adsorption. It indicates that there is another factor (or factors) that play an important role in $\mathrm{Cu}$ adsorption, one of them probably being the surface loading effect, which is higher the higher is GPS concentration.

$\mathrm{Ca}$ and $\mathrm{Mg}$ released during the reaction is always much higher than the amounts of $\mathrm{Cu}$ adsorbed (Table 3), probably because the exchangeable cations are released not only by $\mathrm{Na}^{+}$and $\mathrm{Cu}^{2+}$ ions, but also by $\mathrm{H}^{*}$ ions, as shown by the lower $\mathrm{pH}$ values corresponding to higher $\mathrm{Ca}+\mathrm{Mg}$ released. Therefore, the release of these cations cannot help to estimate $\mathrm{Cu}$ adsorption on interlayer positions. Higher $\mathrm{H}^{*}$ concentrations probably causes a decrease in $\mathrm{Cu}^{2+}$ adsorption competing for exchangeable sites, but the buffering effect of GPS makes it difficult to estimate the extension of this effect.

\section{ACKNOWLEDGEMENT}

This work was supported by the CICYT under project AMB92-0394. 
Table 3.- $\mathrm{Cu}$ adsorbed and $\mathrm{Ca}+\mathrm{Mg}$ desorbed after equilibrating $\mathrm{Cu}+\mathrm{GPS}$ solutions with montmorillonite.

\begin{tabular}{|c|c|c|c|}
\hline $\begin{array}{l}\text { GPS initial } \\
\text { concentration } \\
\text { (mM) }\end{array}$ & $\begin{array}{c}\text { Cu initial } \\
\text { concentration } \\
(\mathrm{ppm})\end{array}$ & $\begin{array}{c}\text { Cu adsorbed } \\
(\mu \theta q / g)\end{array}$ & $\begin{array}{c}\mathrm{Ca}+\mathrm{Mg} \text { desorbed } \\
(\mu \theta q / g)\end{array}$ \\
\hline 0.2 & $\begin{array}{r}0 \\
5 \\
10 \\
20 \\
30\end{array}$ & $\begin{array}{c}0 \\
12.02 \\
19.83 \\
50.11 \\
98.89\end{array}$ & $\begin{array}{l}164.2 \\
189.0 \\
210.2 \\
252.6 \\
290.3\end{array}$ \\
\hline 0.5 & $\begin{array}{r}0 \\
5 \\
10 \\
20 \\
30\end{array}$ & $\begin{array}{c}0 \\
10.07 \\
18.25 \\
31.54 \\
51.99\end{array}$ & $\begin{array}{l}205.4 \\
222.7 \\
239.1 \\
265.6 \\
293.8\end{array}$ \\
\hline 1.0 & $\begin{array}{r}0 \\
5 \\
10 \\
20 \\
30\end{array}$ & $\begin{array}{c}0 \\
12.02 \\
17.06 \\
25.75 \\
30.84\end{array}$ & $\begin{array}{l}252.4 \\
270.2 \\
280.8 \\
296.2 \\
324.7\end{array}$ \\
\hline 2.0 & $\begin{array}{r}0 \\
5 \\
10 \\
20 \\
30\end{array}$ & $\begin{array}{c}0 \\
11.01 \\
16.81 \\
26.25 \\
32.67\end{array}$ & $\begin{array}{l}314.9 \\
321.1 \\
330.2 \\
332.6 \\
353.7\end{array}$ \\
\hline
\end{tabular}

\section{REFERENCES}

BEJARANO, M. and MADRID, L. 1992. Solubilization of heavy metals from a river sediment by a residue from olive oil industry. Environ. Technol. 13: 979-985.

BEJARANO, M., MOTA, A. M., GONÇALVES, M. L. S. and MADRID, L.(1994). Complexation of Pb (II) and $\mathrm{Cu}$ (II) with a residue from olive-oil industry and a synthetic polymer by DPASV. Sci. Total Environ.(submitted).

BUFFLE, J. 1984. "Metal lons in Biological Systems". Marcel Dekker, N. Y.

BUFFLE, J., 1988. "Complexation Reactions in Aquatic Systems". Ellis Honwood (Ed.). John Wiley \& Sons.

BUFFLE, J., ALTMANN, R. S., FILELLA, M., TESSIER, A. 1990. Complexation by natural heterogeneous compounds: site occupation distribution functions, a normalized description of metal complexations. Geochim. Cosmochim. Acta. 54: 1535-1553.

FILELLA, M., BUfFLE, J., LEEUWEN, H. P. 1990. Effect of physico-chemical heterogeneity of natural complexants. Part I. Voltammetry of labile metal-fulvic complexes. Anal. Chim. Acta. 232: 209-223. 
GAMBLE, D. S., UNDERDOWN, A. W., LANGFORD, C. H. 1980. Copper (II) titration of fulvic acid ligand sites with theoretical potentiometric, and spectrophotometric analysis. Anal. Chem. 52: 1901-1908.

GLASS, R. L. 1984. Metal complex formation by glyphosate. J. Agric. Food Chem. 32: 1249-1253.

GLASS, R. L. 1987. Adsorption of glyphosate by soils and clay minerals. J. Agric. Food Chem. 35: 497 . 500 .

HANCE, R. J. 1976. Adsorption of glyphosate by soils. Pestic. Sci. 7: 363-366.

McBRIDE, M. B. 1991. Electron spin resonance study of copper ion complexation by glyphosate and related ligands. Soil Sci. Soc. Am. J. 55: 979-985.

MCCONNELL, J. S. and HOSSNER, L. R. 1985. pH-Dependent adsorption isotherms of glyphosate. J. Agric. Food Chem. 33: 1075-1078.

MORILLO, E. and MAQUEDA, C. 1992. Simultaneous adsorption of chlordimeform and zinc on montmorillonite. Sci. Total Environ. 123/124: 133-143.

MOTEKAITIS, R. J. and MARTELL, A. E. 1985. Metal chelate formation by N-phosphonomethylglycine and related ligands. J. Coord. Chem. 14: 139-149.

PINHEIRO, J. P., MOTA, A. M., SIMOES GONÇALVES, M. L.(1994). Complexation of humic acids with $\mathrm{Cd}$ (II) and $\mathrm{Pb}$ (II). Anal. Chim. Acta (in press).

SHOVAL, S. and YARIV, S. 1979. The interaction between Roundup (Glyphosate) and montmorillonite. Part. 1. Infrared study of the sorption of glyphosate by montmorillonite. Clays Clay Miner. 27: 19-28. SIMOES GONÇALVES, M. L. 1990. "Métodos Instrumentais para Análise de Soluçoes". Fundaçao Calouste Gulbenkian (ed.). Lisbon.

SPRANKLE, P., MEGGITT, W. F., PENNER, D., 1975a. Rapid inactivation of glyphosate in the soil. Weed Sci. 23: 224-228.

SPRANKLE, P., MEGGITT, W. F., PENNER, D., 1975b. Adsorption, mobility, and microbial degradation of glyphosate in the soil. Weed Sci. 23: 229-234.

SUBRAMANIAN, V. and HOGGARD, P. E. 1988. Metal complexes of glyphosate. J. Agric. Food Chem. 36: 1326-1329.

UNDABEYTIA, T., MORILLO, E. and MAQUEDA, C. 1994. Simultaneous adsorption of cadmium and a cationic pesticide on montmorillonite. Toxicol. Environ. Chem. In press.

VAN OLPHEN, H. and FRIPIAT, J. J. (Eds). 1979."Data Handbook for Clay Materials and other Nonmetallic Minerals". Pergamon. Oxtord.

VARADACHARI, C., MONDAL, A. H. and GHOSH, K. 1991. Some aspects of clay-humus complexation: Effect of exchangeable cations and lattice charge. Soil Sci. 151: 227-231. 